technical publications and especially in charts, stereopticon slides, and extension bulletins.

Max W. GARDNer, GEO. K. K. LiNR

\section{WILLIAM DIXON WEAVER}

Dr. William D. Weaver, for a number of years editor of the Electrical World, a man of the true scientific spirit, a friend of education and scholarship, a devotee of literature, an upholder of the finer things of life, and one of the most delightful of companions, died at his home in Charlottesville, Va., on November 2, 1919.

Dr. Weaver was born on August 30, 1857, at Greensburg, Pa. After a year spent in preliminary study at the University of Kentucky, he entered the United States Naval Academy, from which he graduated as cadet engineer in 1880. Only a few months ago Dr. Weaver received the honorary degree of LL.D. from the University of Kentucky. After graduation the young officer served in the Navy for twelve years except for one year's leave of absence in 1884, during which he studied electricity and conducted some investigations in the electrical laboratory of the Sorbonne, Paris, and the School of Electrical Engineering, London. In 1883 he was a member of the U. S. S. Yantic expedition sent to the relief of Lieutenant Greely, the Arctic explorer. When he resigned from the Navy in 1892 he held the relative rank of ensign.

Mr. Weaver's life work was that of an editorial exponent of the science, art and industry of electricity. After resigning from the Navy he spent a year in the business of manufacturing electrical appliances, and he became editor of the Electrical World in 1893. In 1896 the American Electrician was established, and this magazine, a monthly, with $\mathrm{Mr}$. Weaver as editor, became notably successful. Mr. Weaver accomplished the difficult task of making a magazine that was useful and interesting to the "practical" man and at the same time of high technical standing. His gifts as a technical journalist were indeed of a high order. In 1906 the American Electrician was absorbed by the Electrical World, and Mr. Weaver retaining his connection with that paper until May, 1912, when he retired, removing to Charlottesville, Va.

Of a modest, retiring nature, Mr. Weaver did a great deal for electrical advancement, although often he remained in the background, cooperating with others whose names appeared in connection with the particular task in hand. He became an associate of the American Institute of Electrical Engineers in 1887 and became successively a member and a fellow of the society. For six years Mr. Weaver served as manager of the institute, and it is probable that he could have been elected president had he not refused to entertain the honor. On May 16, 1919, as the result of the work of a group of friends and admirers, a bronze tablet was unveiled at the headquarters of the American Institute of Electrical Engineers in recognition of $\mathrm{Mr}$. Weaver's services. It bears a bas-relief portrait and this inscription:

This tablet is dedicated to William Dixon Weaver, engineer, journalist, scholar, to record his influence in the development and promotion of the art and science of electrical engineering.

In $1900 \mathrm{Mr}$. Weaver was appointed by the United States government as an official delegate to the International Electrical Congress at Paris, but, upon his suggestion, the appointment was transferred to Dr. A. E. Kennelly, of Harvard University. He had much to do with the St. Louis (1904) International Electrical Congress, of which he was treasurer and business manager. With Dr.' Kennelly, who was general secretary, he supervised the publication of the Transactions of that congress in three large volumes, published in 1905.

An excellent judge of engineering literature, Mr. Weaver was for several years chairman of the Library Committee of the American Institute of Electrical Engineers. In $1901 \mathrm{Dr}$. S. S. Wheeler purchased the Latimer Clark collection of electrical books and pamphlets and presented it to the institute. Thereafter, as a labor of love, Mr. Weaver edited the Catalogue of the Wheeler Gift of Books, 
Pamphlets and Periodicals in the Library of the American Institute of Electrical Engineers. This catalogue raisonné, in which the late Brother Potamian collaborated with Mr. Weaver was published in two handsome volumes in 1909 and stands as a monument to Mr. Weaver's learning and taste.

It is believed that Mr. Weaver was the first to lay before the late Andrew Carnegie a plan for a home for the engineering societies in New York City which later resulted in the Engineering Societies' Building and the Engineers' Club.

A French scholar and an admirer of French achievements in science and much in French literature, Mr. Weaver was a collector for many years of books, pamphlets and pictures relating to the French Revolution. It is said that few private collections in the United States of books relating to the French Revolution were more complete than his. At one time he wrote about Paris:

I feel more at home in that city than in any other in the world, on account probably of my first impressions of the real world having been received there.

But Lieutenant Weaver was nevertheless a thorough American. During the SpanishAmerican war of 1898 he served as volunteer chief engineer on the U. S. S. Glacier. In 1915, after his retirement, he was asked to become a member of the Naval Advisory Board, but declined on account of his health.

After taking up his home in Charlottesville Mr. Weaver became at once at home in the scholastie atmosphere of the University of Virginia. It is reported that he was offered a place on the faculty of this university a few years ago. Some time before his death $\mathrm{Mr}$. Weaver gave nearly his entire collection of technical books to the University of Virginia.

An independent thinker, Mr. Weaver was tenacious in adhering to his opinions, although quiet and pleasant in manner and not vociferous in advancing his views. He felt strongly that cultural studies should not be neglected in technical education, and deplored a purely materialistic attitude in schools of engineering.
Mr. Weaver was one of the founders of the Illuminating Engineering Society and also of the American Electrochemical Society. $\mathrm{He}$ served for three years as manager of each. $\mathrm{He}$ had also much to do with the formation of the Commission on Resuscitation from Electric Shock. He was a member of the Sociéte Internationale des Electriciens and had been honored by the French government as an officer de l'Instruction Publique.

1 With an acute distaste for public appearances, Mr. Weaver found his greatest pleasure in his home and library. His home life was ideal. In 1900 he married Miss Mildred Niebuhr and the union was blessed with six children. He had been a sufferer from heart trouble and passed away in his sleep.

\section{WiLLIAM E. KEILY}

\section{STATE GRANTS FOR SCIENTIFIC INVESTIGATIONS IN ENGLAND}

A JoINT deputation from the British Medical Association and the British Science Guild waited upon the Right Hon. A. J. Balfour, Lord President of the Council, at the offices of the Privy Council on March 2, to place before him certain considerations with regard to state awards for scientific research.

According to the report in The British Medical Journal Sir Watson Cheyne said that the object of the deputation was to bring forward the question of state awards for scientific work after such work had been done. Scientific workers were assisted by scholarships and so forth while doing their work, but after it was done there was at present no provision for them, although, excited by the interest of their investigation, they had often neglected to make any provision for themselves. Moreover, it was the tradition that a scientific man should immediately publish his discoveries, making no attempt to conceal any knowledge in order to secure personal advantage.

Sir Clifford Allbutt, president of the British Médical Association, referred in particular to the conditions under which medical men worked. Those conditions were governed by the very high-standard of ethics 